\title{
Accurate Measurement and Clinical Significance of Urinary Transforming Growth Factor-Beta
}

\author{
Sotiris Tsakas ${ }^{\mathrm{a}}$ Dimitrios S. Goumenos ${ }^{\mathrm{b}}$ \\ a Laboratory of Biology, Department of Biology, University of Patras, and ${ }^{\mathrm{b}}$ Internal Medicine-Nephrology, \\ University Hospital of Patras, Patras, Greece
}

\section{Key Words}

Transforming growth factor- $\beta_{1} \cdot$ Enzyme immunoassay • Proteinuria $\cdot$ Glomerular injury

\begin{abstract}
Transforming growth factor $\beta_{1}\left(\right.$ TGF- $\left.\beta_{1}\right)$ is the main modulator of the healing process after tissue injury. In the kidney, if TGF- $\beta_{1}$ release is not switched off, extracellular matrix components (ECM) are accumulated and tissue fibrosis occurs. Urinary TGF- $\beta_{1}$ levels reflect its renal production and it has been determined in various types of glomerular disease. In this review, a critical analysis of the different immunoassays that have been used for the measurement of TGF- $\beta_{1}$ in the urine is presented and the importance of the serial determination of urinary TGF- $\beta_{1}$ levels in patients with various types of renal disease is discussed.
\end{abstract}

Copyright $\odot 2006$ S. Karger AG, Basel

\section{Introduction}

Transforming growth factor- $\beta$ (TGF- $\beta$ ) represents a group of $25-\mathrm{kDa}$ proteins, which are actively involved in the development and differentiation of various tissues [1]. TGF- $\beta$ was originally isolated from platelets, but it has also been found in cell cultures of monocytes/macrophages and mesangial cells [2]. Three isoforms of TGF- $\beta$ have been identified in mammalian species: TGF- $\beta_{1}$, TGF- $\beta_{2}$ and TGF- $\beta_{3}$. TGF- $\beta_{1}$, the most important isoform in humans, is secreted from cells in the form of a high-molecular-weight latent complex [3]. Cleavage of this larger precursor molecule is necessary for TGF- $\beta_{1}$ activation $[2,3]$. TGF- $\beta_{1}$ targets specific receptors in various cell types and often exerts its biological effects through autocrine and paracrine pathways $[2,3]$.

TGF- $\beta_{1}$ is the main modulator of the healing process after tissue injury [4]. Normally, its release ceases by feedback mechanisms, when the healing process has been completed [3, 4]. However, if TGF- $\beta_{1}$ release is not switched off, extracellular matrix components (ECM) are accumulated and tissue fibrosis occurs [4]. Increased TGF- $\beta_{1}$ synthesis in the glomeruli and tubulointerstitial area has been identified in rats with subtotal nephrectomy and other types of experimentally induced renal disease $[5,6]$. Upregulation of TGF- $\beta_{1}$ synthesis in the kidney is followed by accumulation of collagen and scarring, whereas the administration of specific antiserum against TGF$\beta_{1}$ results in amelioration of renal damage [7]. Increased synthesis and decreased degradation of ECM components, activation of interstitial fibroblasts and differentiation of tubular epithelial cells into myofibroblasts as well as apoptosis of tubular epithelial cells are stimulated by TGF- $\beta_{1}$ and contribute to the development of renal scarring and to the loss of intrinsic renal cells [8-10]. Although its exact role in the progression of human renal

\section{KARGER}

Fax +41613061234 E-Mail karger@karger.ch www.karger.com
(C) 2006 S. Karger AG, Basel

0250-8095/06/0262-0186\$23.50/0

Accessible online at:

www.karger.com/ajn
Dr. Sotiris Tsakas

Laboratory of Biology, Department of Biology

University of Patras

GR-26500 Patras (Greece)

Tel. +30 2610969 221, Fax +30 2610994 797, E-Mail stsakas@upatras.gr 
disease has not been established, accumulating evidence suggests that TGF- $\beta_{1}$ is actively involved, since increased synthesis of TGF- $\beta_{1}$ m-RNA has been described in the renal tissue of patients with various types of chronic nephropathies $[11,12]$.

Plasma TGF- $\beta_{1}$ levels, measured in patients with various types of renal disease, were found to be similar with those of healthy subjects. Elevated plasma TGF- $\beta_{1}$ levels decreased with the administration of angiotensin II receptor antagonists (ARA) and have been described in renal allograft recipients $[13,14]$. However, serum levels of the growth factor may reflect not only renal produced, but also platelet-derived TGF- $\beta_{1}$ after platelet degranulation. Thus, estimation of platelet activation in the blood samples is necessary [15].

Urinary TGF- $\beta_{1}$ levels, measured in patients with glomerulonephritis and diabetic nephropathy, as well as in renal allograft recipients, were found to be higher than in healthy subjects [16-19]. Increased amounts of TGF- $\beta_{1}$ in the urine have been observed, along with increased excretion of other proteins, such as retinol-binding protein and $\alpha_{1}$-microglobulin that are considered indicators of tubular epithelial cells injury or dysfunction $[19,20]$. These findings, along with the detection of TGF- $\beta_{1}$ mRNA and protein within the tubular epithelial cells in patients with various types of renal disease, suggest that urine TGF- $\beta_{1}$ excretion reflects its intrarenal production [21]. In this review, a critical analysis of the methods measuring TGF$\beta_{1}$ is presented and the importance of its determination in the urine, in relation to the evolution of the disease and to response to treatment is discussed, in patients with different types of renal disease.

\section{Determination of TGF- $\beta_{1}$ in Urine}

\section{Methods for Measuring TGF- $\beta_{1}$}

Urinary TGF- $\beta_{1}$ levels were initially determined by commercially available kits based on enzyme-linked immunosorbent assay (ELISA) using a monoclonal antibody $[22,23]$. Later on, some laboratories developed their own assays $[17,24]$. However, conflicting results have been reported, in patients with various types of renal diseases and this was due to different assays (kits, antibodies and standards), as well as to the various methods used for the activation of TGF- $\beta_{1}$ in the urine. Since TGF- $\beta$ monomers associate with a latent protein [25], the complex needs to be activated by an acidification - alkalization process, in order to determine TGF- $\beta$.

Determination of Urinary TGF- $\beta_{1}$ in Glomerular Disease
Today, several kits for the measurement of TGF- $\beta_{1}$ are commercially available and its determination is based upon sandwich immunoassays, by using either precoated plates with TGF- $\beta_{1}$ soluble receptor or anti-human TGF$\beta_{1}$ (as it can be obtained from the internet, e.g. www.biocompare.com). A polyclonal anti-human TGF- $\beta_{1}$, either biotinylated or HRP conjugated, is used as the detection antibody. It is of note that most of the commercially available kits have been designed to detect TGF- $\beta_{1}$ in serum samples or culture fluids, according to their instruction. However, some of these kits have been used for measurement of urinary TGF- $\beta_{1}$, after modifications that have been introduced by some laboratories in the activation process of TGF- $\beta_{1}[20,26]$. In Europe, the cost of these kits ranges between EUR 450 and 650 (USD 550-750).

\section{Building an EIA for the Measurement of TGF- $\beta_{1}$ Concentration}

In our laboratory, we have focused our interest on the renal expression of TGF- $\beta_{1}$ and its urinary excretion [12, $21]$. We initially tried a commercially available kit for determination of the excreted TGF- $\beta_{1}$. Although our results on its plasma concentration were in agreement with other studies, we noticed a disagreement between urinary TGF$\beta_{1}$ levels and renal expression of this growth factor. The kit was quite expensive and since the results were questionable, we decided to develop an easily reproducible double antibody enzyme immunoassay according to Honkanen et al. [17]. This immunoassay was based on the formation of a sandwich complex of TGF- $\beta_{1}$ with a specific mouse monoclonal and a rabbit polyclonal antibody. The immune complex, in a double-antibody sandwich immunoassay, gives a stronger signal than the competitive ELISA, which uses only one antibody. Thus, lower concentrations of the antigen can be determined and the assay becomes more sensitive. Modifications, depended on the abilities and the supplies of our laboratory, were also made. The building up procedure for the final EIA which is been used in our laboratory $[21,27,28]$, is described below.

Flat-bottomed, high-binding microtiter plates (96 wells) were used (Costar, USA, Cat. No. 2581). Alternatively, plates with 12 strips ( 8 wells each) and the same properties may also be used (Costar, USA, Cat. No. 3590). Wells were coated with $100 \mu \mathrm{l}$ of mouse monoclonal antiTGF- $\beta$ antibodies, $2 \mu \mathrm{g} / \mathrm{ml}$ (Genzyme Diagnostics, USA, code: $80-1835-03$ ) in $0.05 \mathrm{M} \mathrm{Na}_{2} \mathrm{CO}_{3}$ buffer $\mathrm{pH} 9.0$, by overnight incubation, at $4^{\circ} \mathrm{C}$. The wells were filled and washed with PBS, $0.05 \%$ Tween-20, four times. Consequently, $200 \mu$ l Super Block blocking buffer (Pierce, USA) 
were added to all wells - to avoid nonspecific interactions - and incubated for $3 \mathrm{~h}$ at room temperature. Super Block was removed, wells were washed and dried and could then be stored at $4{ }^{\circ} \mathrm{C}$ until assay. On the day of the assay, $100 \mu \mathrm{l}$ of undiluted samples were acid-activated with $50 \mu \mathrm{l} 1 \mathrm{~N} \mathrm{HCl}$ and incubated for $2 \mathrm{~h}$ at $4^{\circ} \mathrm{C}$. Samples were neutralized with the addition of approximately $50 \mu \mathrm{l}$ $1.2 \mathrm{~N} \mathrm{NaOH} / 0.5 \mathrm{~m}$ HEPES and $\mathrm{pH}$ was checked by adding $2 \mu \mathrm{l}$ of the neutralized sample on a pH strip. $100 \mu \mathrm{l}$ of standard dilutions (R\&D Systems, UK) and $100 \mu$ l of neutralized samples were incubated in the wells overnight at $4^{\circ} \mathrm{C}$. The TGF- $\beta_{1}$ bound onto the wells was then detected with a rabbit polyclonal anti-TGF- $\beta_{1}$ antibody (R\&D Systems, UK) labeled with horseradish peroxidase $(200 \mu \mathrm{l}$, $1.5 \mathrm{~h}$ at RT). Peroxidase activity was determined using tetramethylbenzidine (TMB), as a substrate (R\&D Systems, UK). To calculate intra-assay precision, three samples were tested 5 times each on one plate. To calculate interassay precision same samples were tested in 5 separate assays. The intra- and interassay coefficients of variation $(\mathrm{CV})$ were 7.4 and $6.3 \%$, respectively. The recovery of TGF- $\beta_{1}$ standards (50 and $100 \mathrm{pg} / \mathrm{ml}$ ) ranged from 83 to $112 \%$ and the detection limit was $5 \mathrm{pg} / \mathrm{ml}$. To calculate recovery of TGF- $\beta$, three aliquots of the same urine sample were used and 5 and $2.5 \mu \mathrm{l}$ from the $2,000 \mathrm{pg} / \mathrm{ml}$ standard was added, respectively, in the two of them, thus increasing their concentration by 100 and $50 \mathrm{pg} / \mathrm{ml}$. TGF- $\beta$ was determined in the three samples and the recovery was calculated by assuming that their difference should be 100 and $50 \mathrm{pg} / \mathrm{ml}$, respectively. The procedure was performed in triplicate. To determine detection limit of the assay, concentrations less than $20 \mathrm{pg} / \mathrm{ml}$ were used by further diluting standards at concentrations of 10 and $5 \mathrm{pg} / \mathrm{ml}$. Urinary TGF- $\beta_{1}$ excretion was expressed in ng/24 h and plasma TGF- $\beta_{1}$ concentration in $\mathrm{pg} / \mathrm{ml}$. Urine samples were not spiked with albumin to repeat the recovery experiments. It was taken for granted that proteinuria does not interfere in the assay, since the secondary antibody and the standards that we used, are also used for the determination of TGF- $\beta$ in the plasma, where the protein concentration is much higher than in the urine.

Alternatively, an unlabeled rabbit polyclonal anti-TGF$\beta_{1}$ antibody (sc-146) can be used (1:1,000), together with the $A B C$ staining system with similar variation coefficients, recovery and detection limit.

\section{Buying or Building an EIA System?}

A question arises, for a laboratory that wants to determine urinary TGF- $\beta_{1}$ excretion, whether buying a commercially available kit (money consuming - time saving) or using a home made EIA (time consuming - money saving). Since both types of EIAs are reliable, the answer will be based on the balance between cost and time consumption of each laboratory.

As stated above, the cost of an EIA, 96 tests, ranges between EUR 450 and 650. At the same cost the monoclonal antibody for coating the microtiter plates and the polyclonal antibody for the detection of the immunocomplex can be purchased in quantities enough for $4 \times 96$ tests. Although the development of an EIA system is time consuming, it might be money saving in research laboratories where microtiter plates, blocking solutions, PBS, ABC staining system, and substrate solution are parts of its routine. However, the purchase of these secondary but necessary reagents for just one EIA system might be both money and time consuming for a typical clinical laboratory in a General Hospital. In addition, experienced personnel are required in order to build the assay and evaluate its variation coefficients and results.

In table 1 , comparable data are presented from data sheets of some commercially available kits, modified or not, as well as from homemade EIAs.

\section{Urinary TGF- $\beta_{1}$ Excretion in ng/mg Creatinine or $n g / 24 h$ ?}

The unit, which the urinary TGF- $\beta_{1}$ excretion should be determined with, is another issue that needs to be discussed. The ratio of TGF- $\beta_{1}$ over creatinine in urine (pg/ mg creatinine), in random or 24-hour urine collections, used to represent the most commonly used way for the quantization of TGF- $\beta_{1}$ urinary excretion. Others have measured TGF- $\beta_{1}$ in a 3 -hour morning urine collection and expressed its excretion in $\mathrm{pg} / \mathrm{ml}$. We believe that the determination of TGF- $\beta_{1}$ levels in 24-hour urine collection and its expression in $\mathrm{ng} / 24 \mathrm{~h}$, rather than of $\mathrm{pg} / \mathrm{mg}$ creatinine, are more accurate. This opinion is based on the fact that TGF- $\beta_{1}$ is not related with the urinary creatinine excretion, which differs among patients with normal renal function and those with renal insufficiency. Besides, if we compared two groups of patients, with the same urinary TGF- $\beta_{1}$ excretion, in $\mathrm{ng} / 24 \mathrm{~h}$, but with different creatinine clearance and creatinine excretion, the calculation and use of the ratio pg TGF- $\beta_{1} / \mathrm{mg}$ creatine will be misleading, as it will provide varying results. In addition, by expressing urinary TGF- $\beta$ in $n g / 24 \mathrm{~h}$ we do not allow any possible daily variations of TGF levels to interfere in our results. Due to the above, we are convinced that the best way to express urinary TGF- $\beta_{1}$ is in $n g / 24 \mathrm{~h}$, as is the case with proteinuria $(\mathrm{g} / 24 \mathrm{~h})$. 
Table 1. Comparison of variation coefficients among several commercially available kits and homemade EIAs

\begin{tabular}{lllll}
\hline & $\begin{array}{l}\text { Intra-assay } \\
\text { coefficient, } \%\end{array}$ & $\begin{array}{l}\text { Interassay } \\
\text { coefficient, } \%\end{array}$ & $\begin{array}{l}\text { Recovery } \\
\%\end{array}$ & $\begin{array}{l}\text { Lower detection } \\
\text { limit, pg/ml }\end{array}$ \\
\hline Antigenix America & 7.3 & 11.7 & not found & 9 \\
BD Biosciences & not found & not found & not found & 4 \\
R\&D Systems & 7.5 & 12.2 & $81-123$ & 7 \\
Promega & 3.1 & 11.6 & 97 & 15 \\
Ellis et al. [20]* & 8.5 & 13.1 & $92-96$ & not reported \\
Agarwal et al. [26] & 2.7 & 4.8 & 94 & 5 \\
Honkanen et al. [17] & 5.9 & 8.1 & $87-103$ & 5 \\
Goumenos et al. [21] & 7.4 & 6.3 & $83-112$ & 5 \\
\hline
\end{tabular}

* Modified R\&D Systems assay kit.

\section{Urinary TGF- $\boldsymbol{\beta}_{1}$ Levels in Patients with Various Types of Renal Disease}

\section{IgA Nephropathy}

Increased urinary TGF- $\beta_{1}$ excretion has been reported in patients with IgA nephropathy [16, 17, 29-33]. A significant correlation of these levels with the degree of mesangial proliferation, matrix expansion and crescent formation, has also been described $[16,30,32]$. A significant reduction of urinary TGF- $\beta_{1}$ levels was observed with the administration of corticosteroids and angiotensin II receptor blockers (ARBs) [16, 29, 31-33]. This effect of corticosteroids and ARBs is possibly related to TGF- $\beta$ secretion during the inflammatory process in the kidney and to its activation by proteinuria and angiotensin II per se.

Angiotensin II acts as a local growth factor, stimulating cellular hypertrophy and collagen type IV synthesis, in proximal tubular cells, whereas its administration in cultured mesangial cells, increases the levels of active TGF- $\beta_{1}$ $[32,34]$. Urinary TGF- $\beta_{1}$ was significantly reduced in patients with IgA nephropathy, proteinuria $(>1 \mathrm{~g} / 24 \mathrm{~h})$ and impaired renal function after a few weeks of treatment with losartan, but not with amlodipine, although both treatments regulated blood pressure in a similar degree $[29,31]$. Although the reduced with treatment urinary TGF- $\beta_{1}$ levels were higher than those observed in healthy subjects, ARBs may provide a beneficial effect by blocking the production of renal TGF- $\beta_{1}$.

\section{Crescentic Nephritis}

Elevated urinary TGF- $\beta_{1}$ levels have been observed in patients with crescentic nephritis [16, 27, 32]. Extremely high levels were observed in patients who showed no im- provement of renal function with immunosuppressive therapy (steroids and cyclophosphamide) [27]. Patients who improved their renal function with treatment had significantly lower, but still higher levels than those observed in healthy subjects. Urinary TGF- $\beta_{1}$ excretion remained high even after administration of immunosuppressive drugs, in all patients with improved or stabilized renal function [27].

Elevated urinary TGF- $\beta_{1}$ activity has been observed, in experimentally induced anti-GBM (glomerular basement membrane) nephritis, very early in the course of the disease. The time course was identical to that observed for the renal cortical production of TGF- $\beta_{1}$ and it was related to the development of fibrotic lesions [35]. Activation and proliferation of various cells types, via cytokines and growth factors, are involved in the development of crescents [36-41]. The administration of immunosuppressive therapy during the development of cellular crescents can restrict glomerular injury, whereas the development of fibrous crescents suggests a permanent damage. TGF- $\beta_{1}$ is an immune regulator and its increased urinary excretion, during the early course of crescentic nephritis, may represent an index of acute glomerular inflammation. The observation of extremely high urinary TGF- $\beta_{1}$ levels in patients with deteriorating renal function may underline the development of irreversible renal damage in these patients.

\section{Membranous Nephropathy}

Increased urinary TGF- $\beta_{1}$ levels have been reported in nephrotic patients with membranous nephropathy [17, $21,42]$. A significant correlation of these levels with urinary albumin excretion rate and severity of histological involvement (interstitial inflammation and sclerosis in- 
dex) has been observed [17]. Patients with persistent nephrotic syndrome and/or declining renal function had significantly higher TGF- $\beta_{1}$ levels in comparison to patients entering remission, whereas a decrease of urinary TGF- $\beta_{1}$ was noted after administration of steroids or cytotoxic drugs along with a reduction of proteinuria and stabilization of serum creatinine [17].

Elevated TGF- $\beta_{1}$ levels in the urine of nephrotic patients with membranous nephropathy decreased upon remission of nephrotic syndrome with steroids and cyclosporine [21]. TGF- $\beta_{1}$ mRNA and protein expression were also studied in biopsy sections of these patients, using in situ hybridization and immunohistochemistry. TGF- $\beta_{1}$ was localized within tubular epithelial cells, renal interstitium and to a lesser extent within the glomeruli of nephrotic patients, whereas no TGF- $\beta_{1}$ was detected in control biopsies. The extent of TGF- $\beta_{1}$ immunostaining was related to the degree of interstitial inflammation and fibrosis [21].

These findings suggest an upregulation of renal TGF$\beta_{1}$ by filtered protein. It is well known that heavy proteinuria represents an independent risk factor for poor outcome in most types of glomerular disease. The uptake of filtered protein from tubular epithelial cells is followed by activation of genes coding for vasoactive and chemoattractant peptides that contribute to the accumulation of monocytes and myofibroblasts in the renal interstitium leading to inflammation and fibrosis [43-45].

\section{Diabetic Nephropathy}

Increased urinary TGF- $\beta_{1}$ excretion has been reported in patients with insulin-dependent diabetes mellitus (IDDM) and non-IDDM [20, 32, 46-51]. A significant correlation of these levels with urinary excretion of collagen type III (T3C) and retinol-binding protein (RBP) (markers of extracellular matrix synthesis and tubular injury or dysfunction) has been reported in IDDM patients [20]. Urinary TGF- $\beta_{1}$ levels were reported higher in patients with diabetic nephropathy, compared to those of normoalbuminuric IDDM patients with the same duration of diabetes and levels of $\mathrm{HbAlc}[47,48]$. A decrease of these levels along with lower HbA1c levels was observed after a better metabolic control $[52,53]$.

Increased urinary concentration of the TGF- $\beta$ inducible gene h3 (Big-h3), a protein used to assess the biological activity of TGF- $\beta$ in various tissues, has been described in a large number of non-IDDM patients and correlated with stage of disease, degree of proteinuria and $\mathrm{HbA1c}$ [50]. Elevated urinary levels of connective tissue growth factor (CTGF) that is activated downstream from
TGF- $\beta 1$ were also found in diabetic patients, with microand macro-albuminuria $[54,55]$.

ACE inhibitors and/or angiotensin II receptor blockers (ARBs) reduce the urinary TGF- $\beta_{1}$ excretion rate $[33,26$, 55]. Dual renin-angiotensin system (RAS) blockade by ramipril and candersartan in patients with proteinuria $>1 \mathrm{~g} / 24 \mathrm{~h}$ is followed by decrease of urinary TGF- $\beta_{1}$ and CTGF levels [26, 33, 48, 55, 56].

\section{Renal Transplantation}

Elevated urinary TGF- $\beta_{1}$ levels were found during the early post-transplantation period [28]. The extremely high levels of the first few days gradually decrease over a two-month period but remain higher to that of healthy subjects. The increased urinary TGF- $\beta_{1}$ excretion probably represents local production since TGF- $\beta_{1}$ was immunohistochemically identified within the cytoplasm of tubular epithelial cells in patients with delayed graft function [28]. Similar results of elevated TGF- $\beta_{1}$ levels correlated with urinary albumin and a1-microglobulin excretion have been reported in renal allograft recipients, 6 months after transplantation [57]. These findings suggest that, proximal tubular epithelial cell injury is involved in the urinary concentration of TGF- $\beta_{1}$ and in the progressive deterioration of renal function after kidney transplantation [57]. Elevated urinary TGF- $\beta_{1}$ levels which were related to the degree of interstitial fibrosis have been also reported in patients with chronic allograft nephropathy $[58,59]$. The synthesis and expression of TGF- $\beta_{1}$ in the renal allograft is also induced by a direct effect of cyclosporin-A [60].

Thus, upregulation of renal TGF- $\beta_{1}$ production occurs in the transplanted kidney that is particularly susceptible to ischemia/reperfusion injury as a result of the reintroduction of oxygen free radicals, resulting from anaerobic metabolism [61]. Although restoration of injury and improvement of renal function occurs over the following days, urinary TGF- $\beta_{1}$ excretion remains well above normal. This suggests that a low-grade activation of inflammatory process with production of cytokines and growth factors is present in the graft leading to chronic injury [61, 62].

\section{Conclusions}

TGF- $\beta_{1}$ is the main modulator of the healing process and its release ceases when this process has been completed. However, if TGF- $\beta_{1}$ release is not switched off extracellular matrix components are accumulated and tissue 
Table 2. Urinary TGF- $\beta_{1}$ levels in renal diseases and transplantation

\begin{tabular}{|c|c|c|c|c|c|}
\hline \multirow{2}{*}{$\begin{array}{l}\text { Type of } \\
\text { nephropathy }\end{array}$} & \multirow{2}{*}{$\begin{array}{l}\text { Urinary } \\
\text { TGF- } \beta_{1} \text { levels }\end{array}$} & \multicolumn{2}{|c|}{ Relation of urinary TGF- $\beta_{1}$ with } & \multicolumn{2}{|c|}{ Reduction of urinary TGF- $\beta_{1}$ with } \\
\hline & & proteinuria & histological lesions & immunosuppression & ACEI/ARBs \\
\hline $\operatorname{Ig} \mathrm{A}$ & high & no & yes & yes & yes \\
\hline Crescentic & very high $^{\mathrm{a}}$ & no & yes & no & no data \\
\hline Membranous & high & yes & yes & yes $^{\mathrm{b}}$ & no data \\
\hline Diabetic & high & yes & no data & - & yes \\
\hline Transplantation & very high $^{c}$ & no & yes & no data & no data \\
\hline
\end{tabular}

ACEI = Angiotensin-converting enzyme inhibitors; ARBs = angiotensin II receptor blockers.

${ }^{a}$ Very high levels were mainly observed in patients with crescentic nephritis who showed no improvement of renal function, with immunosuppressive therapy.

${ }^{\mathrm{b}}$ Reduction of urinary TGF- $\beta_{1}$ levels was observed in patients with remission of nephritic syndrome, with immunosuppressive treatment.

${ }^{c}$ Very high levels were observed the first few post-transplant days. Urinary TGF- $\beta_{1}$ levels remain high in renal allograft recipients, especially in those with chronic allograft nephropathy.

fibrosis occurs. Upregulation of TGF- $\beta$ in the renal tissue of patients with various types of glomerular disease is usually followed by increased urinary TGF- $\beta_{1}$ excretion (table 2) that reflects its intrarenal production. Urinary TGF$\beta_{1}$ excretion can be accurately determined by sandwich immunoassays using specific antibodies, although commercially available kits or homemade EIAs are, up to now, 'for research use only'.

Elevated urinary TGF- $\beta_{1}$ levels have been reported in patients with acute glomerular inflammation and in renal allograft recipients. The decrease of TGF- $\beta_{1}$ levels in patients with IgA nephropathy with immunosuppressive therapy and in nephrotic patients after remission further supports the implication of this growth factor to the progression of renal disease (table 2). Reduced urinary excretion of TGF- $\beta$ is also observed with the administration of
ACE inhibitors or ARBs in various types of glomerular disease including diabetic nephropathy. These findings (table 2) suggest that ACE inhibitors or ARBs probably provide renal protection by reducing the renal production of TGF- $\beta_{1}$.

Hence, urinary TGF- $\beta_{1}$ appears to be a marker of the severity of the glomerular disease and also a marker of the response to treatment towards inhibition of a permanent damage. However, it is still necessary to be elucidated whether a serial determination of urinary TGF- $\beta_{1}$ levels in the same patients could be used as a noninvasive tool to assess the progression of renal disease and to select patients who might need a more intensive treatment. We believe that further research would reveal the importance of producing 'kits for diagnostic use' for the determination of urinary TGF- $\beta_{1}$.

\section{References}

1 Roberts AB, Sporn MB: Physiological action and clinical applications of transforming growth factor- $\beta$. Growth Factors 1993;8:1-9.

$>2$ Border WA, Noble NA: Transforming growth factor- $\beta$ in tissue fibrosis. $N$ Engl J Med 1994; 9:1286-1291.

3 Lawrence AD: Transforming growth factor- $\beta$ : an overview. Kidney Int 1995;47(suppl 49): S19-S23.

4 Basile DP: The transforming growth factor beta system in kidney disease and repair: recent progress and future directions. Curr Opin Nephrol Hypert 1999;8:21-30.
5 Yamamoto T, Noble NA, Miller DA, Border WA: Sustained expression of TGF- $\beta$ underlies development of progressive kidney fibrosis. Kidney Int 1994;45:916-927.

6 Bollineli JS, Reddi AS: Transforming growth factor- $\beta_{1}$ enhances glomerular collagen synthesis in diabetic rats. Diabetes 1993;42:16731677.

7 Border WA, Okuda S, Languino L, Sporn MB, Ruoslahti E: Suppression of experimental glomerulonephritis by antiserum against transforming growth factor- $\beta_{1}$. Nature $1990 ; 346$ : 371-374.
>8 Desmouliere A, Geinoz A, Gabbiani F, Gabbiani G: TGF- $\beta$ induces a smooth muscle actin expression in granulation tissue myofibroblasts and in quiescent cultured fibroblasts. J Cell Biol 1993;122:103-111.

9 Fan JM, NG YY, Hill PA, Nikolic-Paterson DJ, Mu W, Atkins RC, Lan HY: Transforming growth factor- $\beta$ regulates tubular epithelialmyofibroblast transdifferentiation in vitro. Kidney Int 1999;56:1455-1467. 
10 Miyajima A, Chen J, Lawrence C, Ledbetter S, Soslow RA, Stern J, Jha S, Pigato G, Lemer ML, Poppas DP, Vaughan ED, Felsen D: Antibody to transforming growth factor- $\beta$ ameliorates tubular apoptosis in unilateral ureteral obstruction. Kidney Int 2000;58:2301-2313.

11 Yamamoto T, Noble NA, Cohen AH, Nast CC, Hishiba A, Gold LI, Border WA: Expression of TGF- $\beta$ in human glomerular disease. Kidney Int 1996;49:461-469.

12 Goumenos DS, Tsamandas AC, Oldroyd S, Sotsiou F, Tsakas S, Petropoulou C, Bonikos D, El Nahas AM, Vlachojannis JG: Transforming growth factor- $\beta_{1}$ and myofibroblasts: a potential pathway towards renal scarring in human glomerular disease. Nephron 2001;87: 240-248.

13 Campistol JM, Inigo P, Jimenez W, Lario S, Clesca PH, Oppenheimer F, Rivera F: Losar$\tan$ decrease plasma levels of TGF- $\beta_{1}$ in transplant patients with chronic allograft nephropathy. Kidney Int 1999;56:714-719.

14 Inigo P, Campistol JM, Lario S, Piera C, Campos B, Bescos M, Oppenheimer F, Riviera F: Effects of losartan and amlodipine on intrarenal hemodynamics and TGF-beta (1) plasma levels in a crossover trial in renal transplant recipients. J Am Soc Nephrol 2001;12:822827.

15 Coupes BM, Williams S, Roberts IS, Short CD, Brenchley PE: Plasma transforming growth factor- $\beta_{1}$ and platelet activation: implications for studies in transplant recipients. Nephrol Dial Transplant 2001;16:361-367.

16 Haramaki R, Tamaki K, Fujisawa M, Ikedo H, Haramaki N, Okuda S: Steroid therapy and urinary transforming growth factor- $\beta_{1}$ in IgA nephropathy. Am J Kidney Dis 2001;38:11911198.

17 Honkanen E, Teppo AM, Tornroth T, Groop $\mathrm{PH}$, Groonhagen-Riska C: Urinary transforming growth factor- $\beta_{1}$ in membranous glomerulonephritis. Nephrol Dial Transplant 1997;12:2562-2568.

18 Fagerudd JA, Groop PH, Honkanen E, Teppo A, Gronhagen-Riska C: Urinary excretion of TGF- $\beta_{1}$, PDGF-BB and fibronectin in insulindependent diabetes mellitus patients. Kidney Int 1997;52(suppl 63):S195-S197.

-19 Teppo AM, Honkanen E, Finne P, Tornroth T, Gronhagen-Riska C: Increased urinary excretion of alpha1-microglobulin at 6 months after transplantation is associated with urinary excretion of transforming growth factor-beta 1 and indicates poor long-term renal outcome. Transplantation 2004;78:719-724.

20 Ellis D, Forrest KY, Erbey J, Orchand TJ: Urinary measurement of transforming growth factor- $\beta$ and type IV collagen as new markers of renal injury: application in diabetic nephropathy. Clin Chem 1998;44:950-956.

-21 Goumenos DS, Tsakas S, El Nahas AM, Alexandri S, Oldroyd S, Kalliakmani P, Vlachojannis JG: Transforming growth factor beta-1 in the kidney and urine of patients with glomerular disease and proteinuria. Nephrol Dial Transpl 2002;17:2145-2152.
22 Kanai H, Mitsuhashi H, Ono K, Yano S, Naruse $\mathrm{T}$ : Increased excretion of urinary transforming growth factor beta in patients with focal glomerular sclerosis. Nephron 1994;66: 391-395.

23 Eder IE, Stenzl A, Hobisch A, Cronauer MV, Bartsch G, Klocker H: Transforming growth factor- $\beta 1$ and $-\beta 2$ in serum and urine from patients with bladder carcinoma. J Urol 1996; 156:953-957.

24 Coupes BM, Newstead CG, Short CD, Brenchley PEC: Transforming growth factor- $\beta 1$, in renal allograft recipients. Transplantation 1994;57:1727-1731.

25 Bruijn JA, Roos A, De Geus B, De Heer E: Transforming growth factor- $\beta$ and the glomerular extracellular matrix in renal pathology. J Lab Clin Med 1994;123:34-47.

26 Agarwal R, Siva S, Dunn S, Sharma K: Add-on angiotensin receptor blockade lowers urinary transforming growth factor- $\beta$ levels. Am J Kidney Dis 2002;39:466-492.

27 Goumenos DS, Kalliakmani P, Tsakas S, Sotsiou F, Vlachojannis JG: Urinary transforming growth factor-beta 1 as a marker of response to immunosuppressive treatment, in patients with crescentic nephritis. BMC Nephrol. In press.

28 Goumenos DS, Tsakas S, Savidaki I, Kalliakmani P, Karavias D, Karatzas T, Vlachojannis JG: Urinary transforming growth factor (TGF- $\beta_{1}$ ) excretion in renal allograft recipients during the early post-transplantation period. Ren Fail 2003;25:561-568.

29 Park HC, Xu ZG, Choi S, Goo YS, Kang SW, Choi KH, Ha SK, Lee HY, Han DS: Effect of losartan and amlodipine on proteinuria and transforming growth factor- $\beta 1$ in patients with IgA nephropathy. Nephrol Dial Transplant 2003;18:1115-1121.

30 Murakami K, Takemura T, Hino S, Yoshioka $\mathrm{K}$ : Urinary transforming growth factor- $\beta$ in patients with glomerular diseases. Pediatr Nephrol 1997;11:334-336.

31 Praga M, Andrade CF, Luno J, Arias M, Poveda R, Mora J, Prat MV, Rivera F, Galceran JM, Ara JM, Aguirre R, Bernis C, Marin R, Campistol JM: Antiproteinuric efficacy of losartan in comparison with amlodipine in non-diabetic proteinuric renal diseases: a doubleblind, randomized clinical trial. Nephrol Dial Transplant 2003;18:1806-1813.

32 De Muro P, Faedda R, Fresu P, Masala A, Cigni A, Concas G, Mela MG, Satta A, Carcassi A, Sanna GM, Cherchi GM: Urinary transforming growth factor- $\beta_{1}$ in various types of nephropathy. Pharmacol Res 2004;49:293-298.

-33 Song JH, Lee SW, Suh JH, Hong SB, Kim KA, Kim MJ: The effects of dual blockade of the renin-angiotensin system on urinary protein and transforming growth factor-beta excretion in 2 groups of patients with IgA and diabetic nephropathy. Clin Nephrol 2003;60: 318-326.
34 Kagami S, Border W, Miller DE, Noble NA: Angiotensin II stimulates extracellular matrix synthesis through induction of transforming growth factor- $\beta$ expression in rat glomerular mesangial cells. J Clin Invest 1994;93:24312437.

35 Noh JW, Wiggins R, Phan SN: Urine Transforming Growth Factor- $\beta$ activity is related to the degree of scarring in crescentic nephritis in the rabbit. Nephron 1993;63:73-78.

36 Atkins RC, Nicolic-Paterson DJ, Song Q, Lan HY: Modulators of crescentic glomerulonephritis. J Am Soc Nephrol 1996;7:22712278.

37 Ng YY, Fan JM, Mu W, Nikolic-Paterson DJ, Yang WC, Huang TP, Atkins RC, Lan HY: Glomerular epithelial-myofibroblast transdifferentiation in the evolution of glomerular crescent formation. Nephrol Dial Transpl 1999; 14: 2860-2872.

-38 Alpers CE, Hudkins KL, Floege J, Johnson R: Human renal cortical interstitial cells with some features of smooth muscle cells participate in tubulointerstitial and crescentic glomerular injury. J Am Soc Nephrol 1994;5: 201-210.

- 39 Toth T, Toth-Jakatics R, Jimi S, Ihara M, Urata $\mathrm{H}$, Takebayashi S: Mast cells in rapidly progressive glomerulonephritis. J Am Soc Nephrol 1999;10:1498-1505.

40 Goumenos D, Tsomi K, Iatrou C, Oldroyd S, Sungur A, Papaioannides D, Moustakas G, Ziroyannis P, Mountokalakis T, El Nahas AM: Myofibroblasts and the progression of crescentic glomerulonephritis. Nephrol Dial Transplant 1998;13:1652-1661.

41 Kanemoto K, Usui J, Tomari S, Yokoi H, Mukoyama M, Aten J, Weening JJ, Nagata M: Connective tissue growth factor participates in scar formation of crescentic glomerulonephritis. Lab Invest 2003;83:1615-1625.

42 Dominguez GC, Costa RS, Dantas M, Kimachi T, Coibra TM: Transforming growth factor beta activity in urine of patients with glomerulonephritis. Braz J Med Res 1995;28:10611064.

43 Jerums G, Panagiotopoulos S, Tsalamandris C, Allen T, Gilbert RE, Comper WD: Why is proteinuria such an important risk factor for progression in clinical trials? Kidney Int 1997; 52(suppl 63):S87-S92.

44 Remuzzi G: Nephropathic nature of proteinuria. Curr Opin Nephrol Hypertens 1999;8: 655-663.

45 Wang Y, Chen J, Chen L, Tay YC, Rangan GK, Harris DCH: Induction of monocyte chemoattractant protein-1 in proximal tubule cells by urinary protein. J Am Soc Nephrol 1997;8:1537-1545.

46 Fagerudd JA, Groop PH, Honkanen E,Teppo AM, Gronhagen-Riska C: Urinary TGF- $\beta_{1}$, PDGF-BB, and fibronectin in insulin-dependent diabetes mellitus patients. Kidney Int 1997;52(suppl 63):S195-S197. 
47 Moyorosi A, Kapoor A, Isono S, Sharma K, Ziyadeh FN: Utility of seum and urinary transforming growth factor-beta levels as markers of diabetic nephropathy. Nephron 2000;86:234-235.

48 Gilbert RE, Akdeniz A, Allen TJ, Jerums G: Urinary transforming growth factor- $\beta$ in patients with diabetic nephropathy: implications for the pathogenesis of tubulointerstitial pathology. Nephrol Dial Transplant 2001;16: 2442-2443.

49 Sato H, Iwano M, Akai Y, Kurioka H, Kubo A, Yamaguchi T, Hirata E, Kanauchi M, Dohi K: Increased excretion of urinary transforming growth factor beta 1 in patients with diabetic nephropathy. Am J Nephrol 1998;18:490494.

-50 Cha DR, Kim IS, Kang YS, Han SY, Han KH, Shin C, Ji YH, Kim NH: Urinary concentration of transforming growth factor- $\beta$-inducible gene-h3 (Big-h3) in patients with type 2 diabetes mellitus. Diabetic Med 2005;22:1420.

-51 Sharma K, Ziyadeh FN, Alzahabi B, McGowan TA, Kapoor S, Kurnik BRC, Kurnik PB, Weisnerg LS: Increased renal production of transforming growth factor $\beta 1$ in patients with type II diabetes. Diabetes 1997;46:854-859.

52 Chaturveti N, Schalkwijk CG, Abrahamian H, Fuller JH, Stehouwer CB: EURODIAB Prospective Complications Study Group. Diabetes Care 2002;25:2320-2327.
53 Flores L, Naf S, Hernaez R, Conget I, Gomis $\mathrm{R}$, Esmatjes E: Transforming growth factor beta at clinical onset of type 1 diabetes mellitus: a pilot study. Diabet Med 2004;21:818822.

54 Gilbert RE, Akdeniz A, Weitz S, Usinger WR, Molineaux C, Jones SE, Langham RG, Jerums G: Urinary connective tissue growth factor excretion in patients with type 1 diabetes and nephropathy. Diabetes Care 2003;26:26322636.

55 Andersren S, Nieuwenhoven FA, Tarnow L, Rossing P, Rossing K, Wieten L, Goldschmeding $\mathrm{R}$, Parving $\mathrm{HH}$ : Reduction of urinary connective tissue growth factor by losartan in type 1 patients with diabetic nephropathy. Kidney Int 2005;67:2325-2329.

56 Houlihan CA, Akdeniz A, Tsalamandris C Cooper ME, Jerums G, Gilbert RE: Urinary transforming growth factor-beta excretion in patients with hypertension, type 2 diabetes and elevated albumin excretion rate: effects of angiotensin receptor blockade and sodium restriction. Diabetes Care 2002;25:1072-1077.
57 Teppo AM, Honkanen E, Finne P, Tornroth T, Gronhagen-Riska C: Increased urinary excretion of $\alpha 1$-microglobulin at 6 months after transplantation is associated with urinary excretion of transforming growth factor- $\beta_{1}$ and indicates poor long-term renal outcome. Transplantation 2004;78:719-724.

58 Boratynska M: Urine excretion of transforming growth factor-beta 1 in chronic allograft nephropathy. Ann Transplant 1999;4:23-28.

59 Grandaliano G, Di Paolo S, Monno R, Stallone G, Ranieri E, Pontrelli P, Gesualdo L, Schena FP: Protease-activated receptor 1 and plasminogen activator inhibitor 1 expression in chronic allograft nephropathy. Transplantation 2001;72:1437-1443.

60 Khanna A, Kapur S, Sharma V, Li B, Suthanthiran M: In vivo hyperexpression of transforming growth factor- $\beta_{1}$ in mice: stimulation by cyclosporine. Transplantation 1997;63: 1037-1039.

61 Amend WJC, Vincenti F, Tomlanovich SJ: The first two post-transplantation months; in $\mathrm{Da}$ novitch GM (eds): Handbook of Kidney Transplantation, ed 3. Philadelphia, Lippincott Williams \& Wilkins, 2001, pp 163-181.

62 Smith SD, Wheeler MA, Lorber MI, Weiss RM: Temporal changes of cytokines and nitric oxide products in urine from renal transplant patients. Kidney Int 2000;58:829-837. 